\title{
Determination of Potentially Toxic Metals in Over-the-Counter Pediatric Drugs and Commonly Consumed Beverages in Nigeria: A Health Concern
}

Oyekunle JA01*, Adekunle AS ${ }^{1}$, Ayinde $\mathrm{AR}^{1}$, Dawodu $\mathrm{MO}^{2}$, Ogunfowokan $\mathrm{AO}^{1}$, Oyinloye $\mathrm{JA}^{3}$ and Ogunwale $\mathrm{TO}^{4}$

${ }^{1}$ Department of Chemistry, Obafemi Awolowo University, Ile-Ife, Nigeria

2Department of Chemistry and Industrial Chemistry, Bowen University, Iwo, Nigeria

${ }^{3}$ Department of Science Laboratory Technology, Osun State College of Technology, Esa-Oke, Osun State, Nigeria

${ }^{4}$ Institute of Ecology and Environmental Studies, Obafemi Awolowo University, Ile-Ife, Nigeria

*Corresponding Author: Oyekunle JAO, Department of Chemistry, Obafemi Awolowo University, Ile-Ife, Nigeria, Tel: +2348035673017; Email: oyekunle@oauife.edu.ng

\section{Abstract}

This study investigated the levels of $\mathrm{Cd}, \mathrm{Cu}, \mathrm{Pb}, \mathrm{Mn}$ and $\mathrm{Zn}$ in over-the-counter (OTC) pediatric drugs and commonly consumed beverages in Nigeria. This was done to evaluate the possible health implications of these metals in humans who regularly consume the products. Seven commonly administered OTC pediatric syrups and eight brands of beverages were randomly purchased from various pharmaceutical shops and stores located within Ile-Ife, Southwestern Nigeria. Metal concentrations in the acid digested samples were profiled using Flame Atomic Absorption Spectrophotometer (FAAS).The mean concentrations $(\mu \mathrm{g} / \mathrm{mL})$ of the metals in the OTC pediatric drugs ranged from Below Detection Limit (BDL) in $\mathrm{Cd}$ to $6.75 \pm 0.06$ in $\mathrm{Pb}$, while for the beverages the mean concentrations ranged between Below Detection Limit $(\mathrm{BDL})$ in $\mathrm{Cd}$ and $8.79 \pm 0.23 \mathrm{in} \mathrm{Zn}$. The Pb levels in the sampled drugs were generally above the threshold levels set by the European Food Safety Authority for children's foods and significantly higher than the values of $\mathrm{Pb}$ in the beverages. Caution should be exercised to avoid indiscriminate administration of the OTC drugs and beverages to infants and children to reduce the prevalence of toxic metals-induced short or long term effects among them.

Keywords: Pediatric drugs; Beverages; Metals; Health

Abbreviations: FAAS: Flame Atomic Absorption Spectrophotometer; BDL: Below Detection Limit; OTC: Over the Counter; CV: Coefficient of Variation.

\section{Introduction}

Monitoring the levels of potentially toxic metals in pediatric drugs and beverages is important because 
potentially toxic metals, such as $\mathrm{Cd}, \mathrm{Cu}, \mathrm{Pb}, \mathrm{Mn}$ and $\mathrm{Zn}$, have far reaching health implications at elevated levels in humans [1-5]. Besides, children and youths are the predominant population group that consumes the classes of consumable items under investigation in this study. Apart from constituting a large percentage of current population, this group also constitutes the future work force of any nation. Also, such monitoring will call the attention of both the producers and consumers of the products to safety levels of the items produced and consumed so as to take necessary precautionary healthpromoting measures. It has been noted that periodic surveillance of contaminants, such as potentially toxic metals in food related items, is advisable because build-up of such contaminants in human systems can result in unpleasant health challenges [6].

The aggressive attention-catching adverts of various soft drinks and beverages on media outlets and cuttingedge marketing strategies coupled with the often elevated temperatures associated with the sub-Saharan Africa, such as Nigeria, has led to an increase in sales and consumption of beverages by a large percentage of Nigerians after a hectic day of work. Similarly, administering drugs to ailing infants is a common phenomenon in Nigeria. This is partly because the most vulnerable time in human life is the first five years of infancy, and it is during this time that between 70 and $80 \%$ of the toxicants that have long resident time in the body are absorbed by humans [7]. One of the most neglected pediatric diseases in Sub-Saharan Africa is metal poisoning, which sadly, still persists in most African countries as a result of the existence of numerous potential sources [8]. In a biomonitoring survey of potentially toxic metal levels in children aged 2 - 6 years in Nigeria, many metals such as $\mathrm{Cr}, \mathrm{Ni}, \mathrm{Mn}, \mathrm{Pb}$ and $\mathrm{Cd}$ and even radioactive elements were detected [9].

It is almost impossible to specifically attribute metal presence in a matrix to a particular source. However, drinking local water supplies, consumption of chicken eggs, beverages (canned and uncanned), vegetables and other food items, use of lead-containing eye cosmetics and herbal concoctions have been identified as significant contributors to children's daily sources of metal exposure [10-12].

On many occasions, drugs are purchased for use from patent stores without prescription by a competent practitioner. Thus, most of these medications are administered before an ailing child is even taken to the hospital. Low literacy level, unemployment, poverty, poor accessibility to proper healthcare and medication are some of the factors responsible for the patronage of patent medicine dealers. A study by Orisakwe, et al. showed that about $99 \%$ of children aged 1- 6 were found to have received medication before seeing a doctor and the usual drugs administered ranged from pain relievers to worm expellers, vitamins, anti-diarrheas and anti malaria drugs [8].

The present study evaluated levels of $\mathrm{Cu}, \mathrm{Pb}, \mathrm{Mn}, \mathrm{Zn}$ and $\mathrm{Cd}$ in popularly consumed beverages and commonly administered over-the-counter (OTC) pediatric drugs sold in Nigeria.

\section{Materials and Methods}

\section{Sample Categories and Size}

Two categories of substances, commonly consumed by infants and children, namely: beverages and pediatric drugs were used for the present study. Eight beverage types (coded B1 to B8) and seven different types of pediatric drugs (coded D1 to D7) were purchased from retailers within Ile-Ife between January and February, 2015.

\section{Pretreatment and Sterilization of Apparatus}

The sample bottles, volumetric flask, Teflon beakers, watch glass and measuring cylinder were first washed with liquid detergent and rinsed with distilled water. These were further soaked in $10 \% \mathrm{HNO}_{3}$ for 48 hours and then finally rinsed with distilled water. The sample bottles, Teflon beakers and watch glass were left to dry in an oven at $105^{\circ} \mathrm{C}$, while the volumetric flask and measuring cylinder were allowed to dry at ambient temperatures under conditions that reduced cross contamination to the barest minimum.

\section{Reagents Used and their Sources}

The reagents used were of analytical grade and they included nitric acid (Riedel-deHaën, Germany), perchloric acid (Riedel-deHaën, Germany). The water used for reagent preparation was triply distilled.

\section{Sample Digestion}

The method described by APHA, et al. [13] was adopted in which case $20 \mathrm{~mL}$ of the properly homogenized beverage or drug sample was added into a Teflon beaker. Accurately measured $5 \mathrm{~mL}$ of $70 \% \mathrm{HNO}_{3}$ was added and the beaker was covered with a watch glass. This was placed on a thermostatically controlled hot plate operated 
at $120^{\circ} \mathrm{C}$ for about 45 minutes until the mixture became clear. Replenishing of the acid content was done at intervals to avoid bringing the content to total dryness. The beaker was taken off the hot plate and allowed to simmer. Additional $5 \mathrm{~mL}$ concentrated $\mathrm{HNO}_{3}$ and $5 \mathrm{~mL}$ $\mathrm{HClO}_{4}$ were added and the beaker was replaced on the hot plate operated at a digestion temperature of $150^{\circ} \mathrm{C}$, and digested further for about 25 minutes after which the digestion was considered complete. The beaker was removed from the hot plate, allowed to simmer and the watch glass was rinsed into the beaker. The content of the beaker was then quantitatively transferred into a volumetric flask and made up with distilled water to the $25 \mathrm{~mL}$ mark. The resulting solutions were analyzed for their trace metal concentration using Atomic Absorption Spectrophotometer (AAS) available at Bowen University, Iwo, Osun State, Nigeria. The AAS was operated as per the manufacturer's manual.

\section{Quantification of Potentially Toxic Metals in the Sample}

The actual metal concentration in each sample was calculated from the relationship:

$$
[\mathrm{M}]_{\mathrm{a}}===[\mathrm{M}]_{\mathrm{i}} \times \text { d.f. }
$$

Where $[\mathrm{M}]_{\mathrm{a}}=$ actual metal concentration in sample; $[\mathrm{M}]_{\mathrm{i}==}$ instrumental metal concentration obtained; and d.f. = dilution factor.

\section{Quality Control Measures Adopted}

The quality control measures adopted were blank determination and spike recovery.

\section{Blank Determination}

Blank determination is an analysis of a sample without the analyte or sample. This was accomplished by measuring out all the reagents used in the sample digestion in the same proportion and digesting them minus the beverage or drug samples. The values of metals obtained were subtracted from the ones of the digested samples.

\section{Recovery Analysis}

For recovery experiments, a given well homogenized beverage or drug sample was divided into two equal portions $\mathrm{A}$ and $\mathrm{B}$. Portion A was spiked with a known concentration (C) of the metal of interest while portion $B$ was left unspiked. Both samples were carried through the digestion stages enumerated earlier. Percentage recovery $(\% \mathrm{R})$ was calculated from the relationship:

$$
\% R=\frac{A-B}{C} \times 100
$$

\section{Statistical Analysis of Results}

The statistical method employed in the trace metal analysis included determination of mean, standard deviation and coefficient of variation.

\section{Results and Discussion}

\section{Evaluation of Analytical Procedures Used}

The reliability of the analytical procedures used in this study was tested in terms of percentage recovery (\%R) and linearity of calibration $\left(\mathrm{r}^{2}\right)$. From their values for each metal determined (Table1), a quantitative agreement was observed with recovery values of potentially toxic metals in the samples ranging from $92.9 \pm 1.3 \%$ of $\mathrm{Cu}$ to $96.7 \pm$ $2.7 \%$ of $\mathrm{Mn}$. The $\% \mathrm{R}$ values obtained were within the $70-$ $110 \%$ range for recovery as stipulated by the EU Guidelines for evaluating accuracy and precision of a method [14]. For the FAAS used, the standard calibration curves obtained showed high level of linearity with values of $\mathrm{r}^{2}$ ranging from 0.9789 for $\mathrm{Pb}$ to 0.9993 for $\mathrm{Zn}$. These values were adjudged reliable to give accurate metal

\begin{tabular}{|c|c|c|c|c|}
\hline Metal & $\begin{array}{c}\text { Current } \\
\text { (mA) }\end{array}$ & $\begin{array}{c}\text { Wavelength } \\
\text { (nm) }\end{array}$ & $\begin{array}{c}\text { Calibration } \\
\left.\text { Curve ( } \mathrm{r}^{2}\right)\end{array}$ & $\% R$ \\
\hline $\mathrm{Cd}$ & 8 & 228.6 & 0.9982 & $95.6 \pm 3.5$ \\
\hline $\mathrm{Cu}$ & 6 & 325.1 & 0.9957 & $92.9 \pm 1.3$ \\
\hline $\mathrm{Mn}$ & 10 & 280 & 0.9981 & $96.7 \pm 2.7$ \\
\hline $\mathrm{Pb}$ & 10 & 282.9 & 0.9789 & $93.8 \pm 5.1$ \\
\hline $\mathrm{Zn}$ & 8 & 214.2 & 0.9993 & $95.2 \pm 2.3$ \\
\hline
\end{tabular}
concentrations contained in the samples.

Table 1: Calibration Parameters of FAAS and Percent Recovery (\%R) of Metals.

\section{Levels of Potentially Toxic Metals in Pediatric Drugs}

The results of levels of potentially toxic metals in OverThe-Counter (OTC) pediatric drugs are summarized in Table 2. None of the OTC pediatric drugs sampled contained $\mathrm{Cd}$ at detectable levels indicating that all the drugs could be safely administered to all the children in the various age groups without fearing any cadmium related ill health consequences. 


\section{Advances in Clinical Toxicology}

\begin{tabular}{|c|c|c|c|c|c|c|}
\hline \multicolumn{7}{|c|}{ Levels of metals $(\boldsymbol{\mu g} / \mathbf{m L})$ in drugs } \\
\hline PediatricDrugs & $\mathbf{C d}$ & $\mathbf{C u}$ & $\mathbf{M n}$ & $\mathbf{P b}$ & $\mathbf{Z n}$ & Total Metal \\
\hline D1 & ND & ND & $0.51 \pm 0.02$ & $2.83 \pm 0.04$ & $1.23 \pm 0.11$ & $4.57 \pm 0.12$ \\
\hline D2 & ND & ND & $0.22 \pm 0.02$ & $6.75 \pm 0.06$ & ND & $6.97 \pm 0.06$ \\
\hline D3 & ND & $0.06 \pm 0.00$ & $0.16 \pm 0.01$ & $2.98 \pm 0.07$ & ND & $3.20 \pm 0.07$ \\
\hline D4 & ND & $0.22 \pm 0.02$ & $0.04 \pm 0.00$ & $3.01 \pm 0.10$ & $5.15 \pm 0.13$ & $8.42 \pm 0.17$ \\
\hline D5 & ND & ND & $0.60 \pm 0.03$ & $2.49 \pm 0.12$ & $0.12 \pm 0.01$ & $3.21 \pm 0.12$ \\
\hline D6 & ND & $0.02 \pm 0.00$ & $0.23 \pm 0.01$ & ND & $1.56 \pm 0.03$ & $1.81 \pm 0.03$ \\
\hline D7 & ND & ND & $2.39 \pm 0.05$ & $4.60 \pm 0.09$ & ND & $6.99 \pm 0.11$ \\
\hline Mean s.d. & ND & $0.04 \pm 0.08$ & $0.52 \pm 0.84$ & $3.24 \pm 2.06$ & $1.15 \pm 1.88$ & $4.95 \pm 4.86$ \\
\hline C V & 0 & 200 & 161.5 & 63.6 & 163.5 & 588.6 \\
\hline
\end{tabular}

Table 2: Levels* of potentially toxic metals in pediatric drugs.

$*$ Value $=$ mean of triplicate determinations \pm s.d.

Copper was not detected (ND) in pediatric drugs coded D1, D2, D5 and D7, while Cu levels $(\mu \mathrm{g} / \mathrm{mL})$ varied between $0.02 \pm 0.00$ in D6 and $0.22 \pm 0.02$ in D4. Assuming the drugs are to be administered at 6 hours intervals of $10 \mathrm{~mL}$ per dosage, the amount of $\mathrm{Cu}$ consumed would be between 0.8 and $8.8 \mu \mathrm{g} / \mathrm{mL}$ per day. These values are quite lower than the Recommended Dietary Allowance and Adequate Intake (RDA/AI) limit of between $200 \mu \mathrm{g}$ per day for infants in the age bracket of 0-6 months and $700 \mu \mathrm{g}$ per day for children in the age bracket of 9-13 years. Recommended Dietary Allowance is the average daily dietary intake level sufficient enough to meet the nutrient requirement of about $97-98 \%$ healthy individuals in a group, while Adequate Intake is a value based on observed or experimentally determined approximations of nutrient intake by a group of health individuals; it is used when an RDA cannot be determined. Thus no adverse effects of copper induced health infarctions are expected as a result of consuming these drugs according to prescription by infants/children. The level of $\mathrm{Cu}$ found in the drugs might only serve as supplement of the daily $\mathrm{Cu}$ requirement for the consumers. The amount of $\mathrm{Cu}$ in the sampled drugs could also ensure the normal growth and development of the children in addition to preventing anemia and strengthening immunity against infections [15].

\begin{tabular}{|c|c|c|c|c|c|c|}
\hline \multicolumn{2}{|c|}{ Cu $(\boldsymbol{\mu g} /$ day) } & \multicolumn{2}{c|}{ Mn $(\boldsymbol{\mu g} /$ day) } & \multicolumn{3}{c|}{ Zn $(\boldsymbol{\mu g} /$ day) } \\
\hline Age & Male & Female & Male & Female & Male & Female \\
\hline 0-6 months & 200 & 200 & 3 & 3 & 2000 & 2000 \\
\hline 7-12 months & 220 & 220 & 600 & 600 & 3000 & 3000 \\
\hline 1-3 years & 340 & 340 & 1200 & 1200 & 3000 & 3000 \\
\hline 4-8 years & 440 & 440 & 1500 & 1500 & 5000 & 5000 \\
\hline 9-13 years & 700 & 700 & 1900 & 1600 & 8000 & 8000 \\
\hline
\end{tabular}

Table 3: RDA/AI* for Copper, Manganese and Zinc in Drugs.

Source: FNB/IOM, 2001 [16]

On the other hand, Mn was detected in all the drug samples at levels that ranged from $0.04 \pm 0.00$ in D4 to $2.39 \pm 0.05 \mu \mathrm{g} / \mathrm{mL}$ in $\mathrm{D} 7$. If the drugs are to be administered at $10 \mathrm{~mL}$ per dosage on six hourly bases, $\mathrm{Mn}$ consumption would range from 1.6 to $95.6 \mu \mathrm{g}$ per day. This dosage could be dangerous for infants in the age bracket of $0-6$ months who require only $3 \mu \mathrm{g}$ of Mn per day (Table 3) depending on the particular drug, while it is considered safe for children in the age bracket of $9-13$ years who could consume up to 1,600 or 1,900 $\mu \mathrm{g}$ of $\mathrm{Mn}$ per day, depending on sex. The benefits of $\mathrm{Mn}$ as it occurred in the sampled OTC drugs could include facilitating normal skeletal growth in infants and children and quick healing of wounds [3]. Wound healing is a complex process that requires increased production of collagen. Manganese is required for the activation of prolidase, an enzyme that aids the production of 
the amino acid, proline, used for collagen formation in human skin cells [3].

Lead levels in the various drugs, ranging from ND in D6 to $6.75 \pm 0.06 \mu \mathrm{g} / \mathrm{mL}$ in D2, were all above the threshold set by EFSA [17]. Thus, only D6 could be regarded as $\mathrm{Pb}$ free. The other drugs contained $\mathrm{Pb}$ at more worrisome levels especially in $\mathrm{D} 2$ where the $\mathrm{Pb}$ level could raise fear of developing symptoms of $\mathrm{Pb}$ poisoning, such as encephalopathy, nausea, anemia, palsy and neuropathy [18], in infants/children on regular administration of D6.A regular and consistent administration of this drug in children could lead to a decreased IQ and cognitive measures, and increased incidence of attention-related behaviours [19].

Levels of $\mathrm{Zn}$ in all the drugs sampled were virtually less than $5.2 \mu \mathrm{g} / \mathrm{mL}$. Thus, $\mathrm{Zn}$ levels were far below the RDA/AI ranges for all the children within 0-13 years range. The implication of the metal levels falling within the tolerable level in the sampled drugs is that it serves the children a whole lot of benefit. For instance, adequate intake of dietary zinc in infants and children reduces their susceptibility to diarrhea, it is estimated that diarrheal diseases result in the deaths of over 1.8 million children less than five years of age in developing countries annually [20]. A 2007 metal analysis of randomized controlled trials concluded that zinc supplementation reduces the frequency, severity, and duration of diarrheal episodes in children less than five years of age [21]. Zinc supplementation is also known to reduce the incidence of lower respiratory infections, such as pneumonia [22].

With the coefficient of variation (CV) values varying from 0.0 in $\mathrm{Cd}$ to $200.0 \mathrm{in} \mathrm{Cu}$, it could be deduced that the potentially toxic metals in the drugs were from widely different sources that resulted in diverse amounts of the metals in the drugs analyzed. Total metal load (in $\mu \mathrm{g} / \mathrm{mL}$ ) of the drugs followed the order: D6 $(1.81 \pm 0.03)<\mathrm{D} 3$ $(3.20 \pm 0.07)<\mathrm{D} 5(3.21 \pm 0.12)<\mathrm{D} 1(4.57 \pm 0.12)<\mathrm{D} 2$ $(6.97 \pm 0.06)<\mathrm{D} 7(6.99 \pm 0.11)$. The results of total metal concentration in D2 and D7were particularly worrisome, as $\mathrm{Pb}$ constituted the bulk of the metals present in these pediatric drugs, with minimal presence of essential metals present in them. Administering of these drugs to infants and children should either be avoided or done with utmost caution, as regular and continuous administration of such drugs could bring about serious lead induced illhealth consequences in the consumers of such drugs.

\section{Levels of Potentially Toxic Metals in Beverages}

Results of levels of potentially toxic metals in the beverages (coded B1-B8) investigated are presented in Table 4.None of the beverages showed any appreciable level of Cd, as it was not detected in any of the beverages; either there was no $\mathrm{Cd}$ at all or $\mathrm{Cd}$ in the samples occurred at Table 4.

\begin{tabular}{|c|c|c|c|c|c|c|}
\hline \multicolumn{7}{|c|}{ Levels of metals $(\boldsymbol{\mu g} / \mathbf{m L})$ in drugs } \\
\hline Code & Cd & Cu & Mn & Pb & Zn & Total Metal \\
\hline B1 & ND & $0.31 \pm 0.06$ & $0.77 \pm 0.04$ & ND & $2.23 \pm 0.13$ & $3.31 \pm 0.15$ \\
\hline B2 & ND & $0.33 \pm 0.00$ & $0.10 \pm 0.03$ & $0.25 \pm 0.06$ & $2.60 \pm 0.21$ & $3.28 \pm 0.22$ \\
\hline B3 & ND & $0.25 \pm 0.02$ & $0.82 \pm 0.08$ & $0.93 \pm 0.08$ & $4.69 \pm 0.31$ & $6.69 \pm 0.33$ \\
\hline B4 & ND & $0.10 \pm 0.01$ & $0.04 \pm 0.01$ & $0.83 \pm 0.03$ & $8.79 \pm 0.23$ & $9.76 \pm 0.23$ \\
\hline B5 & ND & $0.17 \pm 0.03$ & $0.28 \pm 0.03$ & $1.56 \pm 0.11$ & $4.89 \pm 0.12$ & $6.90 \pm 0.17$ \\
\hline B6 & ND & $0.31 \pm 0.02$ & $0.92 \pm 0.06$ & $1.31 \pm 0.09$ & ND & $2.54 \pm 0.11$ \\
\hline B7 & ND & ND & $0.12 \pm 0.02$ & $1.42 \pm 0.20$ & $0.52 \pm 0.10$ & $2.06 \pm 0.22$ \\
\hline B8 & ND & $0.01 \pm 0.00$ & $6.39 \pm 0.11$ & $2.84 \pm 0.15$ & $1.28 \pm 0.07$ & $10.52 \pm 0.20$ \\
\hline Mean \pm s.d. & ND & $0.18 \pm 0.14$ & $1.18 \pm 2.13$ & $1.14 \pm 0.88$ & $3.12 \pm 2.89$ & $5.62 \pm 6.04$ \\
\hline CV & 0 & 77.8 & 180.5 & 77.2 & 92.6 & 428.1 \\
\hline
\end{tabular}

Table 4: Levels* of potentially toxic metals in beverages.

$*$ Value $=$ mean of triplicate determinations \pm s.d.

Levels below the instrumental detection limit. By implication, those who consume these beverages regularly might not experience health effects, such as liver and kidney damage, diarrhea, stomach pains, osteomalacia, fracture, reproductive failure, immune and central nervous systems damage, psychological disorders, lung cancer and DNA damage for which exposure to $\mathrm{Cd}$ has been implicated $[23,24,18]$. 
Most of the beverages investigated come in packs of $750 \mathrm{~mL}$. This is the amount served either at home or at ceremonies per attendee. Sometimes, this amount is served to two or three persons. In a situation where someone drinks a whole pack of $750 \mathrm{~mL}$, with $\mathrm{Cu}$ range of ND in B7 to $0.33 \mu \mathrm{g} / \mathrm{mL}$ in B2 as shown in Table 4 the possible amount of $\mathrm{Cu}$ consumed along would fall within the range 0.0 to $247.5 \mu \mathrm{g} \mathrm{Cu}$, depending on the type of the beverages consumed. With the RDA/AI values of 440 $1300 \mu \mathrm{g} /$ day for age groups of 4 years and above (Table 5 ), the quantity of beverages taken per time might not be sufficient to cater for the amount of $\mathrm{Cu}$ needed for normal functioning of the human systems; other sources of food have to be relied upon. Copper is a required component of many redox enzymes, including cytochrome oxidase and plays a crucial role in neurotransmission and in the strengthening and formation of connective tissues $[25,26]$. Relying on these beverages for the sole source of $\mathrm{Cu}$ needed in the body systems might lead to $\mathrm{Cu}$ deficiency manifesting in neutropenia (abnormally low level of white blood cells), a condition that may be accompanied by increased susceptibility to infections $[27,25]$. However, the copper present in the sampled beverages might help in energy production and assist in iron metabolism [26].

Manganese levels in the beverages ranged from $0.04 \pm$ $0.01 \mu \mathrm{g} / \mathrm{mL}$ in B4 to $6.39 \pm 0.11 \mu \mathrm{g} / \mathrm{mL}$ in B8. This range translates to $30.0-4,792.5 \mu \mathrm{g} / \mathrm{mL}$ in $750 \mathrm{~mL}$ pack of the beverages considered. The RDA/AI value for $\mathrm{Mn}$ is given as $1,500-2,600 \mu \mathrm{g} /$ day for 4 year old individuals and above. Although $\mathrm{Mn}$ is an essential element in the human diet that is responsible for the regulation of reproduction, carbohydrate and lipid metabolism, its deficiency or accumulation of large concentrations inhuman systems can impair the CNS and disrupt homeostatic mechanisms, especially those involving iron metabolism [28]. Thus, beverages B1-B7 would serve as good Mn supplement sources, while regular consumption of B8 might lead to excessive concentrations of $\mathrm{Mn}$ and its attendant ill health manifestations in the body of consumers.

\begin{tabular}{|c|c|c|c|c|c|c|c|}
\hline \multicolumn{2}{|c|}{ Copper $(\boldsymbol{\mu g} / \mathbf{d a y})$} & \multicolumn{2}{c|}{ Manganese $(\boldsymbol{\mu g} / \mathbf{d a y})$} & \multicolumn{2}{c|}{ Zinc $(\boldsymbol{\mu g} / \mathbf{d a y})$} & & \\
\hline Life stage & Age & Male & Female & Male & Female & Male & Female \\
\hline Children & 4-8 years & 440 & 440 & 1500 & 1500 & 5,000 & 5,000 \\
\hline Children & $9-13$ years & 700 & 700 & 1900 & 1600 & 8,000 & 8,000 \\
\hline Adolescents & $14-18$ years & 890 & 890 & 2200 & 1600 & 11,000 & 9,000 \\
\hline Adults & 19 years and older & 900 & 900 & 2300 & 1800 & 11,000 & 8,000 \\
\hline Pregnancy & All ages & & 1000 & & 2000 & & 11,000 \\
\hline Breast feeding & All ages & & 1300 & & 2600 & & 12,000 \\
\hline
\end{tabular}

Table 5: RDA/AI for Zinc, Copper and Manganese in Beverages.

Source: FNB/IOM, 2001 [16]

Levels of $\mathrm{Pb}(\mu \mathrm{g} / \mathrm{mL})$ ranged from $\mathrm{ND}$ in $\mathrm{B} 1$ to $2.84 \pm$ $0.15 \mu \mathrm{g} / \mathrm{mL}$ in $\mathrm{B} 8$, translating to $0.0-4,792.5 \mu \mathrm{g} / \mathrm{mL}$ in 750 $\mathrm{mL}$ pack of the beverages considered. Lead is a highly toxic naturally occurring metal that can cause serious health problems, especially for infants, children and pregnant women. Too much of $\mathrm{Pb}$ in human system can cause damage to the nervous systems, red blood cells, brain and kidneys, and lead to increased risk of hypertension and increased incidence of tremor [19]. Beverages, such as B1 and B2 could be suitable for occasional consumption by children as their $\mathrm{Pb}$ levels were below $0.5 \mu \mathrm{g} / \mathrm{mL}$, but others, such as B3, B4, and B6 should be consumed sparingly, while B5 and B8 should be totally avoided by children. On the other hand, beverages such as B1, B2, B3, B4, B6 and B7 as occasional drinks could be considered safe for adults based on the tolerable
$\mathrm{Pb}$ levels established by EFSA. The implication of the excessive consumption of B3-B8 is that consumers are predisposed to adverse health consequences of high $\mathrm{Pb}$ levels in their systems. In the same vein, it could be particularly devastating for a pregnant adult to indiscriminately consume these drinks as accumulation of $\mathrm{Pb}$ in the woman retards the growth of her foetus and exposes her developing baby to the hazards of $\mathrm{Pb} ; \mathrm{Pb}$ is released from her bones as maternal calcium which would be used in the formation of the foetus bones is transported to the foetus [29].

Zinc levels in the beverages ranged between ND in B6 and $8.79 \pm 0.23 \mu \mathrm{g} / \mathrm{mL}$ in B4. Hence, a pack of $750 \mathrm{~mL}$ of the beverages could contain $\mathrm{Zn}$ level of up to 6,592.5 $\mu \mathrm{g}$ as seen in B4. Thus, Zn levels fell within the RDA/AI ranges 
of 5,000-8,000 $\mu \mathrm{g} \mathrm{Zn/day} \mathrm{for} \mathrm{children} \mathrm{within} \mathrm{4-13} \mathrm{years}$ range, in particular. Generally, values of $\mathrm{Zn}$ content in the beverages indicated that the beverages could serve as sources of $\mathrm{Zn}$ supplements for humans. It is known that $\mathrm{Zn}$ in humans performs catalytic, structural, and regulatory functions in the body [30]. In addition to reducing the susceptibility of infants and children to diarrhea [20], adequate intake of dietary zinc is needed for the immune system to function well, for cell division and growth, wound healing and carbohydrate metabolism; it is also needed for the senses of smell and taste to function properly; the body needs $\mathrm{Zn}$ to grow and develop properly during pregnancy, infancy and childhood, and enhances the action of insulin [31-33]. Zinc supplementation is also known to reduce the incidence of lower respiratory infections, such as pneumonia [22].

The coefficient of variation (CV) values of the metals in the beverages varied from 0.0 in $\mathrm{Cd}$ to $180.5 \mathrm{in} \mathrm{Mn.} \mathrm{The}$ high coefficients of variation reflect a wide variation in the prospective sources of the metals in the commonly consumed beverages implying that the sources of these metals in the analyzed beverages cannot be authoritatively established. Total metal load (in $\mu \mathrm{g} / \mathrm{mL}$ ) of the beverages were of the order: $\mathrm{B} 7(2.06 \pm 0.22)<\mathrm{B} 6$ $(2.54 \pm 0.11)<\mathrm{B} 2(3.28 \pm 0.22)<\mathrm{B} 1(3.31 \pm 0.15)<\mathrm{B} 3$ $(6.69 \pm 0.33)<\mathrm{B} 5(6.90 \pm 0.17)<\mathrm{B} 4(9.76 \pm 0.23)<\mathrm{B} 8$ $(10.52 \pm 0.20)$. With no $\mathrm{Cd}$ and little $\mathrm{Pb}$ in the beverages, moderate consumption of these beverages might generally enhance the body daily requirement of essential micronutrients [34], such as $\mathrm{Cu}, \mathrm{Mn}$ and $\mathrm{Zn}$. Generally, caution should be exercised to avoid indiscriminate consumption of the beverages as some of them (e.g. B3, B4, B5 and B8) if consumed regularly and excessively could result in bioaccumulation of potentially toxic metals in the body and manifest some short or long term individual or synergistic effects, ranging from malfunction of the organs in the body, increased risk of hypertension to increased incidence of tremor [19].

\section{Conclusion}

This study clearly demonstrated that many of the mainstream commonly consumed beverages and OTC pediatric drugs consumed by individuals in all age groups and life stages, are a potential source of potentially toxic metals. In some cases, the extent of the lead levels found in some of the drinks as well as the drugs presents itself as a well established reason for concern, especially considering the fact that the sampled drugs are inadvertently administered to infants and growing children-who are at their most vulnerable stage of development and growth. The results of this study revealed that $\mathrm{Zn}$ and $\mathrm{Mn}$ exhibited highest levels in the beverages, while $\mathrm{Cu}$ and $\mathrm{Cd}$ came up with the lowest levels. In contrast, $\mathrm{Pb}$ and $\mathrm{Mn}$ levels were highest in the sampled pediatric drugs, while $\mathrm{Cu}$ and $\mathrm{Cd}$ had the lowest levels. The high concentration of $\mathrm{Pb}$ in some of the sampled OTC drugs and beverages suggested that the potentially toxic metal contamination might most likely be from anthropogenic sources. It was feared that longterm ingestion of the syrups and beverages containing elevated $\mathrm{Pb}$ levels might constitute a significant source of potentially toxic metal exposure to the populace and should therefore be consumed with caution.

\section{References}

1. Jarup L, Berglund M, Elinder CG, Nordberg G, Vahter $M$ (1998) Health effects of cadmium exposure: a review of the literature and a risk estimate. Scand J Work Environ Health 24(Suppl 1): 1-51.

2. Onianwa PC, Adetola IG, Iwegbue CMA, Ojo MF, Tella OO (1999) Trace potentially toxic metals composition of some Nigerian beverages and food drinks. Food Chemistry 66(3): 275-279.

3. Goyer RA, Clarkson TW (2001) Toxic effects of metals. In: Klaassen CD (Eds.), Casarett and Doull's Toxicology: The Basic Science of Poisons. 6th (Edn.), McGraw-Hill Medical Pub. Division, New York.

4. Nogawa K, Kobayashi E, Okubo Y, Suwazono Y (2004) Environmental cadmium exposure, adverse effects, and preventative measures in Japan. Biometals 17(5): 581-587.

5. MSF (2012) Report on Lead Poisoning Crisis in Zamfara State, Northern Nigeria. March 2010 - May 2012. Médecins Sans Frontières 333 7th Avenue, New York.

6. Cabrera C, Lorenzo ML, Lopez CM (1995) Lead and cadmium contamination in dairy products and Its Repercussion on Total Dietary Intake. J Agric Food Chem 43(6): 1605-1609.

7. Goldman LR (1995) Unique and vulnerable: Environmental risks facing children and recommendations for response. Environ Health Perspect. 103(6): 13-18. 


\section{Advances in Clinical Toxicology}

8. Orisakwe OE, Roberts II,Bagbi, BM (2016) Elemental Impurities in Nigerian Pediatric Syrups: Mercury in Violation of Standard Guidelines. Am J Ther 23(3): e708-713.

9. Nriagu J, Afeiche M, Linder A, Arowolo T, Ana G, et al. (2008) Lead poisoning associated with malaria in children of urban areas of Nigeria. Int J Hyg Environ Health 211(5-6): 591-605.

10. Kapu MM, Basak B, Job A, Umaru IO, Kalla SM, et al. (1989) Studies on human exposure to environmental lead in Zaria, Nigeria. Trace Elem Med 6: 178-81.

11. Maduabuchi JMU, Nzegwu CN, Adigba EO, Aloke RU, Ezomike CN, et al. (2006) Lead and cadmium exposures from canned and non-canned beverages in Nigeria: a public heath concern. Sci Total Envrion 366(2-3): 621-626.

12. Obi E, Akunyili D, Ekpo B, Orisakwe O (2006) Potentially toxic metal hazards of Nigerian herbal remedies. Sci Total Environ 369(1-3): 35-41.

13. APHA, AWWA, WEF (1998) Standard Methods for the Examination of Water and Wastewater. (Eds) Greenberg AE, Chescen LS, Eaton AD : American Public Health Association, American Water Works Association, Water Environment Federation.

14. European Union (1999) European Union Directive 1999/74/EC. Laying down minimum standards for the protection of laying hens.

15. Djoko KY, Ong CY, Walker MJ, McEwan AG (2015) The Role of Copper and Zinc Toxicity in Innate Immune Defense against Bacterial Pathogens. J Biol Chem 290(31): 18954-18961.

16. Food and Nutrition Board/Institute of Medicine (FNB/IOM) (2001) Manganese. In: Dietary reference intakes for vitamin A, vitamin $\mathrm{K}$, boron, chromium, copper, iodine, iron, manganese, molybdenum, nickel, silicon, vanadium and zinc. National Academy Press, Washington DC, pp: 394-419.

17. EFSA (2010) European Authority Food Safety Report Panel on Contaminants in The Food Chain. European Authority Food Safety 8(4): 1570.

18. Afal A, Weiner SW (2014) Metal Toxicity. Medicine Medscape 81(4): 338-347.
19. NIEHS (2014) Lead: National Institute of Environmental Health Sciences, 111 T.W. Alexander Drive, Research Triangle, NC 27709.

20. Boschi-Pinto C, Velebit L, Shibuya K (2008) Estimating child mortality due to diarrhoea in developing countries. Bull World Health Organ 86(9): 657-736.

21. Aggarwal R, Sentz J, Miller MA (2007) Role of zinc administration in prevention of childhood diarrhea and respiratory illnesses: a metal-analysis. Pediatrics 119(6): 1120-1130.

22. Bhutta ZA, Black RE, Brown KH, Gardner JM, Gore S, et al. (1999) Prevention of diarrhea and pneumonia by zinc supplementation in children in developing countries: pooled analysis of randomized controlled trials. Zinc Investigators' Collaborative Group. J Pediatr 135(6): 689-697.

23. Friberg L, Norberg GF, Vouk VB (1986) Toxicology of potentially toxic metal. Elsevier/North Holland Biomedial Press, pp: 293-541. Cersosimo MG, Koller WC (2007) The diagnosis of manganese-induced parkinsonism. NeuroToxicology 27(3): 340-346.

24. Orish EO, John KN (2009) Lead and cadmium levels of commonly administered pediatric syrups in Nigeria: a public concern? Sci Total Environ 407(23): 59935996.

25. Drewnowski A (2010) The nutrient food index helps to identify healthy,affordable foods. Am J Clin Nutr 91(4): 1095-1101.

26. Prohaska JR (2011) Impact of ccopper limitation on expression and fuction of multicopper oxidases. Adv Nutr 2(2): 89-95.

27. Brewer GJ (2010) Copper toxicity in general population. Clin Neurophysiol 121(4): 459-460.

28. Cersosimo MG, Koller WC (2007) The diagnosis of manganese-induced parkinsonism. NeuroToxicology 27(3): 340-346

29. Lynn LB (2008) The proposed lead NAAQS: Is consideration of cost in the clean air act's future? Environmental Quality Management 18(1): 79-84.

30. Hambridge KM, Krebs NF (2007) Zinc deficiency: a special challenge. J Nutr 137(4): 1101-1105. 
31. Mason JB (2011) Vitamins, trace mineral and other micronutrients. In: Goldman L, et al. (Eds.), Goldman's Cecil Medicine, 24th Edition, Philadelphia, PA, Elsevier Saunders.

32. Salwen MJ (2011) Vitamins and Trace Elements. In: McPherson RA, et al. (Eds.), Henry's Clinical Diagnosis and Management by Laboratory Methods, 22nd (Edn.), Philadelphia, PA: Elsevier Saunders.
33. Krebs NF (2013) Update on zinc deficiency and excess in clinical pediatric practice. Ann Nutr Metabol 62(1): 19-29.

34. Williams AB, Ayejuyo 00, Ogunyale AF (2009) Trace metal levels in fruit juices and carbonated beverages in Nigeria. Environ Monit Assess 156(1-4): 303-306. 